\title{
Use of Pesticide, Harmful Chemicals, Antibiotic During Sun-Drying of Fish - Safe or Dangerous for Consumers' Health?
}

\author{
M A Mansur ${ }^{1 *}$, M N Uddin ${ }^{1}$, M N Haider ${ }^{1}$, Md. Manik Mia ${ }^{2}$ and Daisuke Kimura ${ }^{3}$ \\ ${ }^{1}$ Department of Fisheries Technology, Bangladesh Agricultural University, Bangladesh \\ ${ }^{2}$ Department of Fisheries, Quality Control Laboratory, Bangladesh \\ ${ }^{3}$ Department of Health Professor, Kobe Women's University, Japan
}

Submission: May 25, 2019; Published: June 11, 2019

Corresponding author: M A Mansur, Department of Fisheries Technology, Faculty of Fisheries Bangladesh Agricultural University, Mymensingh-2202, Bangladesh

\section{Introduction}

In Bangladesh fish catch and production by aquaculture has been increasing year by year. At present the annual fish catch and production by aquaculture is nearly 4 million tons. A sizeable quantity of fish is dried in sunlight annually in Bangladesh. Air drying is also practiced in some places of Bangladesh but mostly the sun-drying is practiced throughout the country. Both small fish and large fish are sun-dried during winter season because weather condition e.g. temperature, relative humidity, less rain is favorable for sun-drying of fish. Both freshwater fish and sea fish are sun-dried throughout the country. The sun-dried fishes are marketed in the domestic market in Bangladesh as well as exported to the international market. There are some problems with the traditional sun-drying process/technique which are summarized below:

i. Drying of fish depends on whether condition, particularly atmospheric temperature, sunlight, less humidity, less rain.

ii. No hygienic condition is maintained during drying of fish.

iii. Sometimes unpleasant odour develops which is not liked by the consumers.

iv. Products become very tough in texture, dark in colour.

v. The sun-dried fish become contaminated.

vi. The sun-dried fish most often infested with blowfly larvae, mites, beetles etc. as it is dried in the open and unprotected area.

vii. It requires considerable time to reconstitute.

viii. Trimming loss before drying cause decrease of yield and composition. ix. Moisture content in the final product is usually higher which cause storage problem.

x. The quality and palatability of the product often lowered due to the faulty or uncontrolled production and storage.

xi. Since it is a slow process considerable loss of quality takes place during this preservation technique.

Considering the above problems many suggestions were recommended to improve the sun-drying of fish in Bangladesh. The important suggestions were on the Quality of raw fish, sanitation and hygienic condition, processing and preparation of raw fish for drying, drying method, and Storage of the product. It was also advised to use 'tent drier' or to use covering net to prevent infestation and contamination from fly and birds. Some drying yards followed the above suggestions and quality of the sun-dried fish was improved. But the extent of infestation by fly, mosquito, birds etc., remained unchanged throughout the country. Tent drier, Improved Solar Drier, Covering Net were used by a limited number of processors in a limited number of drying yards. But the overall condition remains unchanged. Due to awareness of the buyers, consumers, regulatory agencies of Government the processors started to think about the quality of the product, also the safety and sanitation of the product during sun-drying of fish.

In doing so the processors started thinking about the way of reducing the infestation with insect larvae, fly, mites, beetles etc. Unfortunately, many processors wrongly use pesticides, insecticides, harmful chemicals e.g. DDT, formalin, petroleum e.g. kerosene to reduce infestation. It is known from the experience that these materials are dangerous for health. The processors use these materials on fish without any training, without knowing 
any appropriate dose, without permission from the appropriate authority. Sometimes they keep it secret, sometimes they claim that they are trying to reduce infestation, they have seen in some neighboring countries, they received consultant advice about the use of chemicals, insecticides, pesticides, antibiotics during fish drying. But they don't use chemicals, antibiotics, pesticides on the fish which they eat, the marketable products are prepared by the use of chemicals, antibiotics, pesticides. Sometimes dose is much above the MAL (Maximum Allowable Limit). Sometimes sun-drying is very unplanned. Much time difference between fish catch and beginning of drying is a common practice which cause a certain degree of spoilage before the beginning of sundrying.

\section{Opinion Regarding the Latest Situation}

Among the processed fish in Bangladesh the sun-dried fish is consumed in huge quantity. So considerable attention by the appropriate authority is necessary regarding the matter. The following points may be considered: a. Use of Antibiotics, Chemicals, Pesticides may be banned during sun-drying of fish.

b. Frequent inspection and lab test should be executed about the presence of such dangerous materials. If necessary Mobile Court can take the matter into consideration.

c. Dipping fish into a salt solution (2 to 5\%) before drying may be suggested.

d. Sun-drying process, along with other fish processing technologies, may be conducted by applying HACCP Principles and Rules in Bangladesh to achieve products safety by a safe process.

e. Modified atmosphere packaging, antioxidants, fumigation may be practiced for a longer shelf-life of the sundried fish and safety of consumers' health.

\section{Your next submission with Juniper Publishers} will reach you the below assets

- Quality Editorial service

- Swift Peer Review

- Reprints availability

- E-prints Service

- Manuscript Podcast for convenient understanding

- Global attainment for your research

- Manuscript accessibility in different formats (Pdf, E-pub, Full Text, Audio)

- Unceasing customer service

Track the below URL for one-step submission https://juniperpublishers.com/online-submission.php 